\title{
Modeling of Prediction Tuberculosis Prevalence Based Geographically Weighted Poisson Regression
}

\author{
Suprajitno $^{1}$, Sri Mugianti ${ }^{2}$, Wiwin Martiningsih ${ }^{3}$, Wagiyo ${ }^{4}$ \\ Lecture at Nursing Department \\ Poltekkes Kemenkes Malang \\ Poltekkes Kemenkes Semarang
}

\begin{abstract}
Tuberculosis is an infectious disease was cause of death. Tuberculosis patient were continues each year. In epidemiology, the environment and the human were two factors of tuberculosis prevalence, particularly individuals at risk of infection. Basically, tuberculosis prevalence able to predicted with statistically to determine of the two main factors in epidemiology. The purpose of this research was to produce a formula prediction model based GWPR (Geographically Weighted Poisson Regression). Methods: Research design was descriptive. The research sample as much as $111 \mathrm{~Tb}$ patients were selected by simple random sampling, which all patients were recorded in Dinas Kesehatan Kota and Kabupaten Blitar on 2015, January - May. Inclusion criteria were Non MDR (multi drug resistance) and not being hospitalized. Environmental factors were predictors is spacious house, spacious living room, spacious bedrooms, number of bedroom windows, spacious bedroom window, living room temperature, humidity living room, and the amount of sunlight entering the homes of people Tb. The human factor was a patient body weight. Result:, where $X_{1}=$ weight, $X_{2}=$ area of homes of people, $X_{3}=$ spacious living room patients, $X_{4}=$ spacious bedrooms patients, $X_{5}=$ number of bedroom window sufferers, $X_{6}=$ spacious bedroom window sufferers, $X_{7}=$ the temperature of the patient's living room, $X_{8}=$ humidity living room patients, and $X_{9}=$ the amount of light entering the living room. Analysis: Formula produce a proportion of $0.07 \%$ and a predictor effect by $27 \%$. Discuss: Before using a formula to predict tuberculosis prevalence needed to measurements variables and population that can be predicted precisely match the desired time.
\end{abstract}

Keywords: Tuberculosis, Prediction, GWPR

\section{Introduction}

A study in 2013 shown the proportion of Tuberculosis (Tb) patients in the province of East Java in 2013 who received treatment for less than 1 year as much as $0.2 \%$ below the National as much as $0.4 \%$. In epidemiology, Indonesia still the third ranks number of cases of tuberculosis in the world after India and China. Every year there are 250,000 new cases of tuberculosis and about 140,000 was death caused by $\mathrm{Tb}$ (PDPI, 2006).

Tuberculosis is caused by Mycobacterium Tuberculosis which can be transmitted directly by droplet nuclei when talking and coughing. Indirect transmission occurs in the environment (place) whith high humidity such as houses which are poorly ventilated, less sunlight into the house, the slum population, and poor environmental sanitation. Another factor affecting the transmission of tuberculosis is endurance. A person's endurance greatly affected the level of immunity, daily nutrition, healthy habits every day, and responsiveness while experiencing the first symptoms. Also, the density of housing and slums are transmission risk factors for tuberculosis especially active TB patients living in these places.

Based on the presence of patients, the prevalence of tuberculosis can be predicted through variables that exist in people. According to Nakaya (2005) that GWPR (Geographically Weighted Regression Poisson) can be used to predict the incidence of diseases including region-based where was predicted measured by specific region to generate a prediction formula.

\section{Method}

The design of this study was used descriptive, followed by preparation of the formula. The population was all patients with tuberculosis where recorded in the register of patients throughout Public Health Center area of the City Health Office of Blitar on January until April 2015, as many as 158 patients. The sampling method was used simple random sampling (simple random sampling), inclusion criteria of non MDR (multi drug resistance) and not being hospitalized. The sample size required by the National incidence proportion of $0.4 \%$ and the expected precision of $95 \%$ are as many as 111 patients. Variables collected data: (1) immunity, (2) smoking, (3) nutritional status, (4) the first examination when there are symptoms, (5) air circulation in the home, (6) the amount of incoming sunlight, (7) sanitary home environment, and (8) the number of family members at home. Collecting data used questionnaires and tools appropriate variables. Time data collection was conducted from May to August 2015. The data collection at home for tuberculosis spread over 3 districts in Kota Blitar and 15 districts in Kabupaten Blitar. Data collection conducted interviews and measurements. The data were dercriptive analysed and used a GWR4. Ethical clearance was approval from the Health Research Ethics Committee of Poltekkes Kemenkes Malang by register number: 009/KEPK-POLKESMA/2015 dates June $16^{\text {th }}, 2015$.

\section{Result}

General characteristics of the patient and the environment tabulated in Tables 1, 2, 3, and 4. 


\section{International Journal of Science and Research (IJSR) \\ ISSN (Online): 2319-7064 \\ Index Copernicus Value (2013): 6.14 | Impact Factor (2015): 6.391}

Table 1: General characteristics of the Tb patient

\begin{tabular}{|c|l|c|c|}
\hline No. & \multicolumn{1}{|c|}{ Characteristics } & $\mathrm{f}$ & $\%$ \\
\hline 1 & Sex: & & \\
& - Male & 67 & 60,4 \\
& - Female & 44 & 39,6 \\
\hline 2 & Education: & & \\
& - Not school & 7 & 6,30 \\
& - Elementary school & 40 & 36,03 \\
& - Junior school & 31 & 27,92 \\
& - Senior school & 28 & 25,23 \\
& - Higher & 5 & 4,50 \\
\hline 3 & Place of first Tb diagnosis: & & \\
& - Hospital & 41 & 36,93 \\
& - Public Health Center & 42 & 37,84 \\
& - Other Health Care & 28 & 25,23 \\
\hline 4 & Supervisors taking medication at & & \\
& home: & 82 & 73,87 \\
& - Exist & 29 & 26,13 \\
& - No exist & & \\
\hline 5 & Smoking habit: & & \\
& - Until now & 6 & 5,40 \\
& - Sometime & 40 & 36,03 \\
& - Never & 60 & 54,05 \\
& - No answer & 5 & 4,50 \\
\hline 5 a & Total of cigarettes a day (now and & & \\
& ever): & 10 & 21,74 \\
& - O.5 pack & 27 & 58,70 \\
& - 1 pack & 2 & 4,35 \\
& $-1,5$ pack & 6 & 13,04 \\
& - 2 pack & 1 & 2,17 \\
& -3 pack & & \\
\hline 6 & Scaring sign of BCG vaccination: & & \\
& - Nothing & 44 & 39,64 \\
& - There is and normal & 51 & 45,95 \\
& - There is but abnormal & 16 & 14,41 \\
\hline
\end{tabular}

Table 2: Physical condition of Tb patient

\begin{tabular}{|c|c|c|c|c|c|}
\hline \multirow{2}{*}{ No. } & \multirow{2}{*}{ Physical condition } & \multicolumn{4}{|c|}{ Value } \\
\cline { 3 - 6 } & & $\min$ & $\max$ & average & sd \\
\hline 1 & Old (years) & 18 & 83 & 47,01 & 17,28 \\
\hline 2 & Height $(\mathrm{cm})$ & 145 & 180 & 159,82 & 8,42 \\
\hline 3 & Weight $(\mathrm{kg})$ & 30 & 75 & 48,74 & 9,50 \\
\hline 4 & Body Mass Index & 12,49 & 31,16 & 19,08 & 3,48 \\
\hline
\end{tabular}

Table 3: The existence of a window in the Tb patient bedroom

\begin{tabular}{|c|c|c|}
\hline Window in the Tb patient bedroom & $\mathrm{f}$ & $\%$ \\
\hline Ever & 91 & 82,0 \\
Never & 20 & 18,0 \\
\hline
\end{tabular}

Table 4: Home environment condition of Tb patient

\begin{tabular}{|c|c|c|c|c|c|}
\hline & & \multicolumn{4}{|c|}{ Value } \\
\cline { 3 - 6 } No. & Home condition & $\min$ & $\max$ & average & sd \\
\hline 1 & House large $\left(\mathrm{m}^{2}\right)$ & 12,50 & 400,00 & 83,96 & 65,33 \\
\hline 2 & ${\text { Living room large }\left(\mathrm{m}^{2}\right)}^{2}$ & 4,00 & 80,00 & 17,88 & 12,06 \\
\hline 3 & $\begin{array}{c}\text { Tb patient bedroom large } \\
\left(\mathrm{m}^{2}\right)\end{array}$ & 2,00 & 24,00 & 7,57 & 3,09 \\
\hline 4 & $\begin{array}{c}\text { Tb patient bedroom } \\
\left.\text { window large ( }{ }^{2}\right)\end{array}$ & 0,00 & 24,00 & 1,19 & 2,35 \\
\hline 5 & $\begin{array}{c}\text { Living room temperature } \\
\left.{ }^{\mathrm{O}} \mathrm{C}\right)\end{array}$ & 24,60 & 32,50 & 28,71 & 2,09 \\
\hline 6 & Living room humidity (\%) & 61,00 & 96,00 & 79,17 & 9,49 \\
\hline 7 & $\begin{array}{c}\text { Living room sunlight } \\
\text { entering (Lux) }\end{array}$ & 3,00 & 892,00 & 93,22 & 151,43 \\
\hline 8 & $\begin{array}{c}\text { Tb patient bedroom } \\
\left.\text { temperature ( }{ }^{\mathrm{O}} \mathrm{C}\right)\end{array}$ & 24,2 & 32,5 & 28,7 & 1,9 \\
\hline 9 & $\begin{array}{c}\text { Tb patient bedroom } \\
\text { humidity (\%) }\end{array}$ & 59,00 & 98,00 & 79,05 & 9,64 \\
\hline 10 & $\begin{array}{c}\text { Tb patient bedroom } \\
\text { sunlight entering (Lux) }\end{array}$ & 1,00 & 303,00 & 46,73 & 61,31 \\
\hline
\end{tabular}

Tb patient habits when coughing tabulated in table 5 .

Table 5: Cross tabulation Tb patient habit when coughing with hand wash, a tool used to shut of mouth, and head position when coughing

\begin{tabular}{|c|c|c|c|c|c|c|}
\hline \multirow{2}{*}{$\begin{array}{l}\text { Hand wash habit } \\
\text { after coughing }\end{array}$} & \multirow{2}{*}{\multicolumn{3}{|c|}{ Tool used to shut of mouth }} & \multicolumn{2}{|c|}{ Head position when coughing } & \multirow{2}{*}{ Total } \\
\hline & & & & Straight & Turning & \\
\hline \multirow{8}{*}{ Sometimes } & No material & Shut of mouth habit when coughing & No shut & $4(3.60 \%)$ & $1(0.90 \%)$ & $5(4.50 \%)$ \\
\hline & \multirow{2}{*}{ Cloth } & \multirow{2}{*}{ Shut of mouth habit when coughing } & Shutting & $8(7.21 \%)$ & $3(2.70 \%)$ & $11(9.91 \%)$ \\
\hline & & & No shut & $1(0.90 \%)$ & $0(0.00 \%)$ & $1(0.90 \%)$ \\
\hline & \multirow{2}{*}{ Hand } & \multirow{2}{*}{ Shut of mouth habit when coughing } & Shutting & $23(20.72 \%)$ & $4(3.60 \%)$ & $27(24.32 \%)$ \\
\hline & & & No shut & $2(1.80 \%)$ & $0(0.00 \%)$ & $2(1.80 \%)$ \\
\hline & Paper towels & Shut of mouth habit when coughing & Shutting & $6(5.41 \%)$ & $0(0.00 \%)$ & $6(5.41 \%)$ \\
\hline & \multirow{2}{*}{ Total } & \multirow{2}{*}{ Shut of mouth habit when coughing } & Shutting & $37(33.33 \%)$ & $7(6.31 \%)$ & $44(39.64 \%)$ \\
\hline & & & No shut & $7(6.31 \%)$ & $1(0.90 \%)$ & $8(7.21 \%)$ \\
\hline \multirow{7}{*}{ Always } & No material & Shut of mouth habit when coughing & No shut & $1(0.90 \%)$ & $1(0.90 \%)$ & $2(1.80 \% \%)$ \\
\hline & \multirow{2}{*}{ Cloth } & \multirow{2}{*}{ Shut of mouth habit when coughing } & Shutting & $7(6.31 \%)$ & $1(0.90 \%)$ & $8(7.21 \%)$ \\
\hline & & & No shut & $1(0.90 \%)$ & $0(0.00 \%)$ & $1(0.90 \%)$ \\
\hline & Hand & Shut of mouth habit when coughing & Shutting & $3(2.70 \%)$ & $0(0.00 \%)$ & $3(2.70 \%)$ \\
\hline & Paper towels & Shut of mouth habit when coughing & Shutting & $1(0.90 \%)$ & $0(0.00 \%)$ & $1(0.90 \%)$ \\
\hline & \multirow{2}{*}{ Total } & \multirow{2}{*}{ Shut of mouth habit when coughing } & Shutting & $11(9.91 \%)$ & $1(0.90 \%)$ & $12(10.81 \%)$ \\
\hline & & & No shut & $2(1.80 \% \%)$ & $1(0.90 \%)$ & $3(2.70 \%)$ \\
\hline \multirow{7}{*}{ Never } & No material & Shut of mouth habit when coughing & No shut & $9(8.11 \%)$ & $2(1.80 \% \%)$ & $11(9.91 \%)$ \\
\hline & Cloth & Shut of mouth habit when coughing & Shutting & $5(4.50 \%)$ & $0(0.00 \%)$ & $5(4.50 \%)$ \\
\hline & Hand & Shut of mouth habit when coughing & Shutting & $18(16.22 \%)$ & $1(0.90 \%)$ & $19(17.12 \%)$ \\
\hline & \multirow{2}{*}{ Paper towels } & \multirow{2}{*}{ Shut of mouth habit when coughing } & Shutting & $6(5.41 \%)$ & $2(1.80 \% \%)$ & $8(7.21 \%)$ \\
\hline & & & No shut & $1(0.90 \%)$ & $0(0.00 \%)$ & $1(0.90 \%)$ \\
\hline & \multirow{2}{*}{ Total } & \multirow{2}{*}{ Shut of mouth habit when coughing } & Shutting & $29(26.13 \%)$ & $3(2.70 \%)$ & $32(28.83 \%)$ \\
\hline & & & No shut & $10(9.01 \%)$ & $2(1.80 \% \%)$ & $12(10.81 \%)$ \\
\hline \multirow{3}{*}{ Total } & No material & Shut of mouth habit when coughing & No shut & $14(12.61 \%)$ & $4(3.60 \%)$ & $18(16.22 \%)$ \\
\hline & \multirow{2}{*}{ Cloth } & \multirow{2}{*}{ Shut of mouth habit when coughing } & Shutting & $20(18.02 \%)$ & $4(3.60 \%)$ & $24(21.62 \%)$ \\
\hline & & & No shut & $2(1.80 \% \%)$ & $0(0.00 \%)$ & $2(1.80 \% \%)$ \\
\hline
\end{tabular}

Volume 5 Issue 7, July 2016 www.ijsr.net

Licensed Under Creative Commons Attribution CC BY 
International Journal of Science and Research (IJSR)

ISSN (Online): 2319-7064

Index Copernicus Value (2013): 6.14 | Impact Factor (2015): 6.391

\begin{tabular}{|c|c|c|c|c|c|c|}
\hline \multirow{8}{*}{$\begin{array}{l}\text { Hand wash habit } \\
\text { after coughing }\end{array}$} & \multirow{2}{*}{\multicolumn{3}{|c|}{ Tool used to shut of mouth }} & \multicolumn{2}{|c|}{ Head position when coughing } & \multirow{2}{*}{ Total } \\
\hline & & & & Straight & Turning & \\
\hline & \multirow{2}{*}{ Hand } & \multirow{2}{*}{ Shut of mouth habit when coughing } & Shutting & $44(39.64 \%)$ & $5(4.50 \%)$ & $49(44.14 \%)$ \\
\hline & & & No shut & $2(1.80 \% \%)$ & $0(0.00 \%)$ & $2(1.80 \% \%)$ \\
\hline & \multirow{2}{*}{ Paper towels } & \multirow{2}{*}{ Shut of mouth habit when coughing } & Shutting & $13(11.71 \%)$ & $2(1.80 \% \%)$ & $15(13.51 \%)$ \\
\hline & & & No shut & $1(0.90 \%)$ & $0(0.00 \%)$ & $1(0.90 \%)$ \\
\hline & \multirow{2}{*}{ Total } & \multirow{2}{*}{ Shut of mouth habit when coughing } & Shutting & $77(69.37 \%)$ & $11(9.91 \%)$ & $88(79.28 \%)$ \\
\hline & & & No shut & $19(17.12 \%)$ & $4(3.60 \%)$ & $23(20.72 \%)$ \\
\hline
\end{tabular}

\section{Result Analysis With gwr4}

Subjects were at radius longitude $112.068870-112.259260$ East and latitude $8.035920-8.251010$ South with area around $20.956959 \times 23.916951 \mathrm{~km}^{2}$. AICc (the corrected Akaike Information Criterion) value as much as 12.729386 obtained subtraction AICc value of before and after model corrective. Deviance value as much as 5.74. The predictor influence (percent deviance explained) as much as 0.273013 .

Data based of $\mathrm{Tb}$ prevalence predictor was scar sign at upper right arm because at the age of one month must be acquire BCG immunization. Predictor value presented at table 6 .

Table 6: Predictor value of $\mathrm{Tb}$ prevalence

\begin{tabular}{|c|c|c|c|}
\hline Variables / Predictor & $\beta$ & Standard error & Average of value \\
\hline Intercept & -0.823 & 0.09 & \\
\hline Weight $\left(X_{1}\right)$ & 0.589 & 0.03 & 0.594 \\
\hline Large of $\mathrm{Tb}$ house $\left(\mathrm{m}^{2}\right)\left(\mathrm{X}_{2}\right)$ & 0.090 & 0.05 & 0.091 \\
\hline Large of $\mathrm{Tb}$ living room $\left(\mathrm{m}^{2}\right)\left(\mathrm{X}_{3}\right)$ & -0.140 & 0.03 & 0.141 \\
\hline Large of $\mathrm{Tb}$ bedroom $\left(\mathrm{m}^{2}\right)\left(\mathrm{X}_{4}\right)$ & 0.103 & 0.01 & 0.103 \\
\hline Amount of $\mathrm{Tb}$ windows bedroom $\left(\mathrm{X}_{5}\right)$ & -0.163 & 0.02 & 0.165 \\
\hline Large of $\mathrm{Tb}$ windows bedroom $\left(\mathrm{m}^{2}\right)\left(\mathrm{X}_{6}\right)$ & -0.093 & 0.01 & 0.093 \\
\hline Temperature of $\mathrm{Tb}$ living room $\left(\mathrm{X}_{7}\right)$ & -0.423 & 0.04 & 0.427 \\
\hline Humidity of $\mathrm{Tb}$ living room $(\%)\left(\mathrm{X}_{8}\right)$ & 1.004 & 0.04 & 1.013 \\
\hline Amount of sunlight entry living room (Lux) $\left(\mathrm{X}_{9}\right)$ & -0.072 & 0.03 & 0.072 \\
\hline
\end{tabular}

Poisson regression equation as follows:

$$
\begin{aligned}
\log _{8}(Y)= & -0,823+0,589 * X_{1}+0,090 * X_{2}-0,140 * X_{3}+0,103 * X_{4}-0,163 * X_{5}-0,093 * X_{6} \\
& -0,423 * X_{7}+1,004 * X_{8}-0,72 * X_{9}
\end{aligned}
$$

Which were $X_{1}, X_{2}, X_{3}, \ldots, X_{9}$ value average of predictor distribution.

\section{Discussion}

Sex of tuberculosis patient by male as $60.4 \%$ and female as $39.4 \%$. This is consistent with Riskesdas (2013) also that proportion of sex of tuberculosis patient with positive diagnosis by male as much as $57.1 \%$ and female as much as $42.9 \%$. Mean, research subject is similar to Riskesdas sample in Indonesia on 2013.

Tuberculosis patient educations around $30 \%$ are senior and high school. Patients who has a level of secondary education is expected to easily understand the matter of health education about the regularity of taking medications to optimize healing, being positive attitude for prevention and treatment, and behave good habitual in healing. This habit can be used a model for himself and other including no spitting in any place. Made (2013) written that Tb patient education levels improve the perception and knowledge so that patients have treatment compliance. This is according that tuberculosis curing can be done through intensive treatment program and adherence tuberculosis patients taking the medication.

First place as the tuberculosis diagnosis was precise and in accordance with the expectations of the treatment program. Mean, patients self-conscious on health for symptoms are coughing not recover as long two weeks, loss weighted so thin, and night sweats. However, patient conscious in the passive category because tuberculosis patient checks back again to Public Health Center (PHC) after giving health education from the nurses related to sign and symptom of tuberculosis. Moreover, patient conscious to check deserves appreciation.

Tuberculosis patient who has a supervisors in medication (Pengawas Minum Obat / PMO) as much as $73,87 \%$. Bagoes et all (2006) mention that supervisors taking medication have been very important and be required in tuberculosis treatment, and must be have a good knowledge in order to have a good attitude and practice for being supervised. PHC nurses say that every PMO has got health education about tuberculosis treatment and protection; taking medication schedule at PHC; time to take medication; and how to take medication. Health education is done at the start of drug administration after definite diagnosis tuberculosis suffering.

Tuberculosis patients who have smoking habit around $41,43 \%$ (until now and sometime) and as much as $58.70 \%$ who has smoke habit as one pack (12 cigarettes) per day. Sri et all (2011) written that smoking habits have value $R R=2.407 \quad(p=0.011)$ on the incidence of tuberculosis. Smoking habits lead to pulmonary dysfunctional which can causes unfulfilled and even aggravate the body's oxygen needs even complicate treatment because there are carcinogens and chemical materials that antagonist treatment. 


\section{International Journal of Science and Research (IJSR) \\ ISSN (Online): 2319-7064 \\ Index Copernicus Value (2013): 6.14 | Impact Factor (2015): 6.391}

Tuberculosis prevention can be done through the administration of the BCG vaccine at infants up to 3 months in the upper right arm. Vaccinations can enhance actively immunity is marked of normal scarring. Patients with no sign of scarring as much as $39.64 \%$ and there but not normal as much as $14.41 \%$, this situation is fairness to illness. Harni (2005) written that the time schedule of immunization related to the tuberculosis incidence with $\mathrm{OR}=3.82(\mathrm{p}=0.00)$, this result confirms the importance of $\mathrm{BCG}$ immunization to prevent tuberculosis disease. Tuberculosis prevention have been conducted and pursued for a long time with the BCG vaccine that aims to actively body immunity. Zakiudin (2001) explains that immunization is a mechanism formed specific immunity through the introduction of antigen.

The lowest age of tuberculosis patient was 18 years, illustrates that need attention because it is the next generation of Indonesia progresivity. If no, can be a burden of the State and society. Hazard, tuberculosis patient may be dependency and as case become multi drug resistance (MDR) patient. So, would burden State because treatment funding is increasing, family not productive and intensively as supervisors taking medication, and society because his can spread of disease.

Tuberculosis patient who have a body mass index (table 2) in thin category was harmfully to healing process, because healing process requires sufficient nutrition intake. PHC responsibility increased of nutrition intake as effort to optimal healing process, which can be measured from the tuberculosis patient body mass index. While, nurse effort is doing health education about kind of food can be used as an alternative nutrition, adequate nutritional intake, and how to prevent vomiting when food is consumed.

Tuberculosis patients who have shut of mouth habit and turning head position when coughing as much as 11 (9.91\%) and did not shut of mouth habit but turning head position when coughing as much as $4(3.60 \%)$. Patient habitual of turning head position when coughing should be reinforcement that is a good habit to prevent transmission by droplet infection. Patient habitual of shut of mouth habit but straight head position when coughing as much as 77 $(69.37 \%)$. This habit needs to be modified because majority of tuberculosis patient have been educated.

Patients who have a habit of not shutting the mouth and do not head turning when coughing as much as 19 (17.12\%), this is a bad habit because it can be transmitted to other people or family members through droplet infection. As the cause of the transmission are average of large of window bedroom patient as $1.19 \mathrm{~m}^{2}$, the lowest living room temperature as $24.6{ }^{\circ} \mathrm{C}$, living room humidity as $96 \%$, and levels of sunlight entering living room as 1 Lux (table 4). Bad habits when coughing be supported by never and sometimes to hands wash after coughing as much as $86.9 \%$, but always wash their hands after coughing as much as $13.51 \%$ (table 5). A bad patient habit is the responsibility of health resource to improve the knowledge and skill of patient to hand washing anything after cough. However, good habits should be motivated and retained because patients have had the self-awareness to well behave. Hand wash has been declared by Ministry of Health Republic of Indonesia as a habit of individuals and families through the Clean and
Healthy Lifestyle (PHBS) that must be done anywhere and anytime.

Spacious house of tuberculosis patients smallest is $12 \mathrm{~m}^{2}$, which illustrates that, the welfare and lives in category the pre-prosperous family. Environmental factors that affect the global prevalence of tuberculosis are the bedroom patient's temperature, bedrooms patient humidity, and the amount of sunlight into the bedroom. Space used for tuberculosis patient to activities during the home that are the living room and bedrooms patients which an important factor in healing and transmission of tuberculosis.

Average patient bedroom temperature as $28.7 \pm 1.9{ }^{\circ} \mathrm{C}$ and patient bedroom humidity as $79.05 \pm 9.64 \%$ (table 4). Bedroom temperature and humidity are not good in continuous and long term can be risk factor for healthy family member. Pudji Lestari research (2011) shown that humidity is above $75 \%$ has twice the risk for children who live at home contracting of tuberculosis.

Transmission risk of tuberculosis is supported by absence of sunlight entry living room, which is only in the range of 1-3 Lux. Febrianti research (2011) shown that variables related with tuberculosis incidence are living room sunlight entering, large of bedroom window, and type of flooring. This research result is consistent by Febrianti (2011), that majority (82\%) of patient bedroom has not window and average of window bedroom large as $1.19 \mathrm{~m}^{2}$. This condition that a little of window bedroom large not possible to air exchange and no sunlight entering for bedroom patient. Wells (2006) written that ultraviolet of sunlight besides to help to construction of Vitamin D also enhanced of Tb natural immunity. The study acknowledged how important the sunlight is very helpful for family members especially children are vulnerable to illness. Theory is written that a good mycobacterium tuberculosis breeding are temperature range of $22-28{ }^{\circ} \mathrm{C}$, very dark environment, and humid.

Forward, the predictor variables value (table 6) substituted in Poisson regression equation produced a value of 11.902. So, done to proportionally toward population (158 people) produced a value of $0.07 \%$. Next step, do to prediction of tuberculosis incidence in accordance existing population of Kota and Kabupaten Blitar. Population registered in Statistics Indonesia in 2013, population of Kota Blitar as much as 135,702 peoples and Kabupaten Blitar as much as 1,116,639 peoples. Prediction of tuberculosis incidence based on proportionally in Kota Blitar as much as 103 (around 102.2) peoples and Kabupaten Blitar as much as 842 (around 841.1) peoples.

Poisson regression model can be revealed through the natural logarithm (exponential) of the event as a linear function result of a set of predictors. Predictor influence based on the value of percent deviation is 0.273013 , meaning predictor variables affect only $27 \%$, while $73 \%$ influenced by other variables. Other variables as predictors of tuberculosis prevalence are slums, patient habits spit or sputum dispose, people immune around the patient, and transmission by the eating or drinking equipment.

\section{Volume 5 Issue 7, July 2016 www.ijsr.net}




\section{International Journal of Science and Research (IJSR) \\ ISSN (Online): 2319-7064}

Index Copernicus Value (2013): 6.14 | Impact Factor (2015): 6.391

Ministry of Health Republic of Indonesia Regulation No. 1077/Menkes/Per/V/2011 about Sanitation Code of Air in Space House mentioned that tuberculosis is common in environments with not good indoor of air quality. Prequisite of good air quality are a temperature range of $18-30{ }^{\circ} \mathrm{C}$, lighting more than 60 Lux, and humidity 40-60\%. House environment of tuberculosis patient supported as predictors of Poison regression formula because the minimum requirements of air quality are not fulfilled, that are the lighting ranges $46.73 \pm 61.31$ Lux and humidity over $60 \%$ $(79.05 \pm 9.64)$ but the temperature was matching to the regulation.

Quality of tuberculosis patient air environment is necessary to the restructuring. Restructure referred to the regulations are to be improved air circulation by adding a mechanical ventilation, lighting in a house is necessary based on the requirements of a minimum $60 \mathrm{Lux}$, and installing glass roof. Such efforts can be done by PHC because it has a program for environmental sanitation. So, PHC roles should be improved through environmental detection activities and provision of facilities to house tuberculosis patients.

\section{Conclusion}

1) Environmental factors as becoming global predictor are the bedroom temperature, bedroom humidity, and the amount of sunlight entering bedroom of tuberculosis patients. Environmental factors as becoming local predictor (direct) are a spacious house, spacious living room, large of bedroom, number of bedroom window, large of bedroom window, the living room temperature, the living room humidity, and the amount of sunlight entry living room.

2) Human factor as becoming a global predictor is the body mass index and as local predictor is patient weight.

3) Poisson regression formula to predict the prevalence of tuberculosis in Kota and Kabupaten Blitar is $\log _{e}(Y)=-0.823+0.589 * X_{1}+0.090 *$ $X_{2}-0.140 * X_{3}+0.103 * X_{4}-0.163 * X_{5}-$ $0.093 * X_{6}-0.423 * X_{7}+1.004 * X_{8}-$ $0.072 * X_{9}$

with proportionally is $0.07 \%$ less than Nationality proportion of tuberculosis prevalence as $0.4 \%$.

4) Predictor variables affect only $27 \%$, while $73 \%$ influenced by other variables.

\section{Recommendation}

Recommended can be given that:

1) Any use of the formula of tuberculosis incidence need to be recounted predictor value to match the time predicted.

2) Other predictors associated with tuberculosis disease should be identified and analysed further in order to increase the predictive power.

\section{Acknowledgement}

This research finance supported by Board of Development and Empowerment of Health Human Resources of Ministry of Health Republic of Indonesia on 2015.

\section{References}

[1] Chapter 13. Poisson Regression Analysis, http://www.oxfordjournals.org/our_journals/tropej/onlin e/ma_chap13.pdf

[2] Chapter 4 Poisson Models for Count Data, http://data.princeton.edu/wws509/notes/c4.pdf

[3] André Damião da Costa Martins, 2011. Stochastic models for prediction of pipe failures in water supply systems, Dissertação para obtenção do Grau de Mestre em Matemática e Aplicações, https://fenix.tecnico.ulisboa.pt/downloadFile/395143446 036/Tese_Andre_Martins.pdf

[4] Auda Fares, 2011. Seasonality of Tuberculosis. Journal Global Infectious Dissease 2011 Jan-Mar: 3(1): 46-55. http://www.ncbi.nlm.nih.gov/pmc/articles/PMC3068579

[5] Badan Litbangkes Kementerian Kesehatan RI, 2013. Riset Kesehatan Dasar 2013.

[6] Bagoes Widjanarko, Priyadi Nugraha Prabamukti, dan Nunuk Widyaningsih, 2006. Analisis Faktor-Faktor Yang Mempengaruhi Praktik Pengawas Minum Obat (PMO) dalam Pengawasan Penderita Tuberkulosis Paru di Kota Semarang. Jurnal Promosi Kesehatan Indonesia Vol. 1 / No. 1 / Januari 2006: 15-24.

[7] Crawley, M.J. Statistics: An Introduction Using R, 10. Analysing Proportion Data: Binomial Errors, http://www.math.chs.nihonu.ac.jp/ tanaka/files/kenkyuu/ProportionData.pdf

[8] Febrianti, Thresya, 2011. Hubungan Karakteristik Lingkungan Fisik Rumah Dengan Kejadian Tb Paru Positif di Kecamatan Karangrayung Kabupaten Grobogan. Tesis. Semarang: Universitas Diponegoro.

[9] Germ'an Rodr'1guez, 2013. Models for Count Data With Overdispersion, http://data.princeton.edu/wws509/notes/c4a.pdf

[10]Harini, Setyo, 2005. Hubungan waktu pemberian imunitas BCG dengan kejadian tuberkulosis paru pada anak di Kabupaten Sleman Propinsi Daerah Istimewa Yogyakarta. Tesis. Yogyakarta: Universitas Gadjah Mada.

[11] Murtiningsih, D.A., Tri Pujikurniawan, dan Farid Setyo Nugroho, 2014. Pengaruh Luas Ventilasi terhadap Kejadian Tb Paru di Wilayah Kerja Puskesmas Sukoharjo Kabupaten Sukoharjo Tahun 2013. Skripsi. Surakarta: Universitas Muhammadiyah Surakarta.

[12] Nakaya, T., A. S. Fotheringham, C. Brunsdon, M. Charlton, 2005. Geographically weighted Poisson regression for disease association mapping. Statistics in Medicine, Volume 24, Issue 17, pages 2695-2717, 15 September 2005.

[13] Peraturan Menteri Kesehatan Republik Indonesia NOMOR 1077/MENKES/PER/V/2011 tentang PEDOMAN PENYEHATAN UDARA DALAM RUANG RUMAH

[14]Perhimpunan Dokter Paru Indonesia (PDPI), 2006. Tuberkulosis: Pedoman Diagnosis dan Penatalaksanaan di Indonesia.

[15] Pudji Lestari, Florentina Sustini, Anang Endaryanto, and Retno Asih, 2011. Home humidity increased risk of tuberculosis in children living with adult active tuberculosis cases. Universa Medicina, SeptemberDecember 2011, Vol. 30 - No. 3: 138-145. 


\section{International Journal of Science and Research (IJSR) \\ ISSN (Online): 2319-7064}

Index Copernicus Value (2013): 6.14 | Impact Factor (2015): 6.391

[16] Sri Marisya Setiarni, Adi Heru Sutomo, dan Widodo Hariyono, 2011. Hubungan Antara Tingkat Pengetahuan, Status Ekonomi, dan Kebiasaan Merokok dengan Kejadian Tuberkulosis Paru pada Orang Dewasa di Wilayah Kerja Puskesmas Tuan-Tuan Kabupaten Ketapang Kalimantan Barat. Jurnal Kesehatan Masyarakat Vol 5 No. 3, September 2011: 162-232. Yogyakarta: Universitas Ahmad Dahlan.

[17] Wanti, Qomariyatus Solihah, dan Martha Djapawiwi, 2015. Relationship between House Condition and Tuberculosis Incidence in Timor Tengah District. International Journal of Science: Basic and Applied Research (USBAR) (2015) Volume 21, No. 1, pp 344-349. http://gssrr.org/index.php?journal=JournalOfBasicAndA pplied

[18] William A. Wells, 2006. Curing TB with sunlight. Journal of Cell Biology 2006 Mar 27: 172 (7): 958. http://www.ncbi.nlm.nih.gov/pmc/articles/PMC2063771 /\#!po=16.6667

[19]Zakiudin Munasir, 2001. Respons Imun terhadap Infeksi Bakteri. Sari Pediatri, Vol. 2, No. 4, Maret 2001: 193 197.

Volume 5 Issue 7, July 2016 www.ijsr.net 